\title{
INTERFERENCE OF THE NUMBER OF REMOTE CONTROL VALVES IN USE ON THE ENERGY PERFORMANCE OF AN AGRICULTURAL TRACTOR WITH PRODUCTIVITY MANAGEMENT
}

\author{
Lauro S. Neto ${ }^{1 *}$, Leonardo L. Kmiecik ${ }^{1}$, Samir P. Jasper ${ }^{1}$, Gabriel G. Zimmermann ${ }^{1}$, Daniel Savi ${ }^{1}$ \\ ${ }^{1 *}$ Corresponding author. Universidade Federal do Paraná/ Curitiba - PR, Brasil. \\ E-mail: laurostrapasson@ufpr.br | ORCID ID: https://orcid.org/0000-0002-9634-3176
}

\section{KEYWORDS}

power on the drawbar, hydraulic system, operational speed, specific consumption, engine thermal efficiency.

\begin{abstract}
The hydraulic remote control system allows the transfer of energy from the engine through a flow of hydraulic oil to engines and implements pulled by agricultural tractors, which can interfere with its energy and operational performance. This study aimed to evaluate the interference of the number of remote control valves in use on the operational and energy performance of an agricultural tractor, using a productivity management system. The experiment was conducted in a strip-plot design, with five replications and three treatments, which consisted of the number of remote control valves in use $(1,2$, or 3 ), totaling 15 experimental units. The results were subjected to normality and homogeneity tests and analysis of variance, followed by the Tukey test when it was significant. The highest number of valves in use interfered with the operational speed, power and efficiency on the drawbar, specific fuel consumption, and engine thermal efficiency, thus reducing the energy and operational performance of the agricultural tractor.
\end{abstract}

\section{INTRODUCTION}

Agricultural tractors have become over the years indispensable in the field, mainly as a source of power, being considered essential tools due to their versatility and work efficiency (Cutini \& Bisaglia, 2016). These advantages are provided through coupling mechanisms such as the drawbar, power take-off, three-point hitch, and remote control valves, allowing different soil tillage operations, crop implantation, and crop management with the most various agricultural implements.

Climate instabilities, associated with the evolution of cultivars, demand more restrictive agricultural windows to achieve high production rates and low production risks (Boyer et al., 2015). Thus, it is necessary to use mechanized sets of a higher power, aiming at operations at high speeds and capable of pulling large-size implements (Mantovani et al., 2019).

The agricultural tractor has evolved over the years, mainly in architecture and components (Lankenau et al., 2019), also following the evolution of available implements. The hydraulic system underwent improvements that allowed its use in replacing the power take-off, making it possible to work with low engine speeds, ensuring fuel savings and use in pneumatic seeders that require hydraulic flow to drive engines.
The hydraulic system acts as a means of energy transmission in a machine, in which, using a mechanical power source (internal combustion engine), it generates hydraulic power through hydraulic pumps, being again transported as mechanical power (Mialhe, 1980).

The use of hydraulic energy allows reducing wear between components due to the lubricating power of the oil (Wienecke \& Bartz, 1999), generating linear movement and its control, in addition to multiplying forces. Thus, some implements may require higher or lower hydraulic power, interfering directly or indirectly with the energy (Borghia et al., 2014) and operational performance of the agricultural tractor.

The choice and maintenance of operational speed imply the performance and quality of the agricultural operation, as it is related to the power requirement that the machine provides, movement of the wheels, and the traction efficiency (Jasper et al., 2016; Rinaldi et al., 2016). The ability to provide power to pull the implement demonstrates the tractor's ability to operate, in which the power offered on the drawbar is the product between the force exerted on the bar and its speed (Simikić et al., 2012), showing its ability to perform the task, thus expressing its yield (Masiero et al., 2011).

\footnotetext{
${ }^{1}$ Universidade Federal do Paraná/ Curitiba - PR, Brasil.
} 
The highest number of remote control valves in use may affect these parameters since it is known that the hydraulic system requires engine power as an energy source. Thus, it is necessary to determine several parameters to evaluate the operational and energy performance of the agricultural tractor, which must overcome the resistance offered by the implement using the maximum engine power with the minimum expenditure of fuel (Simikić et al., 2014), as hourly fuel consumption represents one of the main costs of the agricultural production (Ajdadi \& Gilandeh, 2011).

Another performance indicator is the specific fuel consumption, which demonstrates how efficiently the engine transforms fuel into work, being defined as the ratio between the mass of fuel consumed in a certain time and the power developed in the drawbar; the lower the specific consumption, the higher the machine efficiency (Farias et al., 2017a).

Power losses during the transmission in agricultural tractors are due to the passive resistance and friction, together with the power absorbed by the hydraulic circuit, which can reach more than 50\% (Molari \& Sedoni, 2008). However, the percentage losses and energy demand of the hydraulic remote control system, provided by the high number of remote control valves in use, are low due to the low oil temperature and working pressure in this system. Therefore, studies are necessary to determine possible interferences from implements, which require high hydraulic power, and their causes in the performance of the moto-mechanized set.

This study aimed to evaluate the interference of the number of remote control valves (RCVs) in use on the operational and energy performance of an agricultural tractor, using a productivity management system.

\section{MATERIAL AND METHODS}

The experiment was carried out at Fazenda Canguiri, located in Pinhais, PR, Brazil, on a concrete floor, following the rules of the American Society of Agricultural Engineers (ASABE, EP 496.3, 2011). During the study, the ambient temperature varied from 26 to $29{ }^{\circ} \mathrm{C}$, and the relative air humidity varied from 30 to $35 \%$. The experimental design consisted of the strip-plot design, with five replications and three treatments, which consisted of the number of pairs (output and return) of remote control valves in use (1, 2, or 3 named $1 \mathrm{RCV}, 2 \mathrm{RCVs}$, and $3 \mathrm{RCVs}$, respectively), totaling 15 experimental units each, corresponding to a 30$\mathrm{m}$ displacement on a six-meter wide concrete track.

The tractor used in the experiment was a Case IH Magnum 340, with a nominal power of $250 \mathrm{~kW}$ and extra power (EPM) of $275 \mathrm{~kW}$, auxiliary front-wheel drive (FWA), 18x4 Full PowerShift transmission, automatic productivity system $(\mathrm{APM})^{2}$, and a maximum flow of remote control valves (RCVs) of 130 liters per minute.

During the experiment, FWD, APM, and EPM were activated, the fuel tank was complete, and the engine load was maintained below 5\% variation. APM performs a function similar to the shifted up-throttle back system described by Farias et al. (2019). In this system, only the

2 APM automatically selects, through the manager, the engine speed and the gear used on the tractor from the desired target theoretical speed, always aiming at the lowest hourly fuel consumption. 3 Considering the extra power $(275 \mathrm{~kW})$. theoretical target speed was defined on the panel, and the software that manages APM chose the appropriate gear and engine speed.

The tractor was assembled with double wheels (front and rear), radial front tires 480/70R34, with internal and external pressures of $96.5 \mathrm{kPa}(14 \mathrm{psi})$ and $82.7 \mathrm{kPa}(12 \mathrm{psi})$, respectively, and radial rear tires $710 / 70 \mathrm{R} 42$, with internal and external pressures of $68.9 \mathrm{kPa}$ (10 psi) and 55.2 (8 psi), respectively, providing anticipation of the front wheel relative to the rear wheel of $1.60 \%$ when FWA is activated.

Mass addition to the tractor consisted of $40 \%$ hydraulic ballast in all front and rear tires (internal and external), plus metallic ballasts in the front (18 45-kg plates) and the rear axle (four 454-kg rings plus two $227-\mathrm{kg}$ rings).

The static mass on tractor axles was determined with a CELMIG CM-1002 scale composed of four platforms. Mass distribution consisted of $42 \%$ in the front axle and $58 \%$ in the rear axle, resulting in $7,823 \mathrm{kgf}$ in the front and $10,803 \mathrm{kgf}$ in the rear, totaling $18,626 \mathrm{kgf}$ and a power-toweight ratio ${ }^{3}$ of $67.73 \mathrm{~kg} \mathrm{~kW}^{-1}$.

A New Holland PL 6015 vacuum planter was used to define the flow in RCVs, following the manufacturer's recommendations for soybean sowing ${ }^{4}$. The adopted vacuum pressure was $5 \mathrm{kPa}$. The hydraulic planter motor required a flow rate of 28 liters per minute, with a pressure of $80 \mathrm{bar}(8 \mathrm{Mpa})$ at the outlet of RCVs, used as a reference in the experiment.

The simulation and measurement of pressure and flow were carried out by three Stauf 400 flow meters. Flow rates were constant at 28 liters per minute in each activated $\mathrm{RCV}$. Therefore, flow rates of 28, 56, and 84 liters per minute were obtained for $1 \mathrm{RCV}, 2 \mathrm{RCVs}$, and $3 \mathrm{RCVs}$, resulting in a hydraulic power of $3.73,7.47$, and $11.20 \mathrm{~kW}$, respectively (Roeber et al., 2016).

A Case IH Steiger tractor, with a $272 \mathrm{~kW}$ power and 16x2 Full PowerShift transmission, double front and rear wheels 710/70/R42 was coupled to the drawbar of the tractor used in the experiment to provide resistance. They were set as a train, providing $103 \mathrm{kN}(10,500 \mathrm{kgf})$ as tractive force, chosen based on the ASABE 497.7 (2011) standard and considering a concrete surface and a $4 \times 2$ FWD tractor, which resulted in an available power on the drawbar of $198.5 \mathrm{~kW}(270 \mathrm{hp})$. The adopted theoretical target speed ${ }^{5}$ was $1.94 \mathrm{~m} \mathrm{~s}^{-1}\left(7 \mathrm{~km} \mathrm{~h}^{-1}\right)$, similar to that recommended for the sowing operation, with the pneumatic metering system, according to Macedo et al. (2016).

The tractor was instrumented with the sensors described below, connected to the data acquisition system (DAS), with a printed circuit board (Jasper et al., 2016). Acquisition frequency was one hertz, with values stored directly on the hard disk.

The slip of the four driving wheels was determined using Autonics E100S encoders, obtained through the rotations of wheels with and without load, determined by [eq. (1)].

$$
\mathrm{SLP}=\left(\frac{\mathrm{NPWL}-\mathrm{NPWN}}{\mathrm{NPWN}}\right) \times 100
$$

\footnotetext{
4 The planter was used only in the choice of pressure and flow rate, not being used in the execution of the experiment.

5 The target theoretical speed corresponds to the speed selected on the tractor panel, which is different from the operational speed, which corresponds to the tractor speed in the experiment.
} 
Where:

SLP is the wheel slip (\%);

NPWL is the number of pulses of the wheel with loaded, and

NPWN is the number of pulses of the wheel with no load.

The power take-off (PTO) allowed measuring the engine speed using an Autonics E100S encoder. The transmission relationship was obtained using a Victor DM6236P digital tachometer. The engine speed was determined according to [eq. (2)].

$$
\mathrm{ES}=\left(\frac{\sum \mathrm{NP}}{\mathrm{t} \times 100}\right) \times 60 \times \mathrm{RT}
$$

Where:

ES is the engine speed (RPM);

$\mathrm{NP}$ is the number of pulses per second in the PTO encoder;

$\mathrm{RT}$ is the engine-PTO transmission ratio, and

$\mathrm{t}$ is the repetition travel time (s).

Fuel consumption was measured by two Flowmate OVAL MIII LSF 45 flow meters, installed in the tractor's fuel supply system (inlet and return to tank). Consumption is given by the difference in the number of pulses emitted by the flow meters, later converted into volume, considering the frequency of $10 \mathrm{~mL}$ per pulse, according to [eq. (3)].

$$
\mathrm{HFC}=\left(\frac{V_{F I}-V_{F R}}{\mathrm{t}}\right) \times 3.6
$$

Where:

HFC is the hourly fuel consumption $\left(\mathrm{L} \mathrm{h}^{-1}\right)$,

$\mathrm{V}_{\mathrm{FI}}$ is the volume of fuel in the inlet flow meter $\left(\mathrm{mL} \mathrm{s}^{-1}\right)$, and

$\mathrm{V}_{\mathrm{FR}}$ is the volume of fuel in the return flow meter to the tank $\left(\mathrm{m} \mathrm{s}^{-1}\right)$.

The force on the drawbar (FDB) was determined with a Bermann load cell with a $300 \mathrm{kN}$ capacity, 2.0+0.002 $\mathrm{Mv} \mathrm{V}^{-1}$ sensitivity, and $0.01 \mathrm{kN}$ precision, properly calibrated and installed in the drawbar coupled to the tractor.

The mean tractive force was determined according to [eq. (4)].

$$
\mathrm{MTF}=\frac{\sum_{\mathrm{i}=1}^{\mathrm{n}} \mathrm{Fi}}{\mathrm{n}}
$$

Where:

MTF is the mean tractive force $(\mathrm{kN})$;

$\mathrm{Fi}$ is the instantaneous tractive force $(\mathrm{kN})$, and $\mathrm{n}$ is the number of data recorded.
The operational speed (OS) was determined by a Vansco 740030A radar, using the number of pulses emitted by the radar during the experiment.

The power available on the drawbar was obtained as a function of force and speed, according to [eq. (5)].

$$
\mathrm{PDB}=\mathrm{MTF} \times \mathrm{OS}
$$

Where:

PDB is the power available on the drawbar $(\mathrm{kW})$;

MTF is the mean tractive force $(\mathrm{kN})$, and

OS is the travel speed $\left(\mathrm{km} \mathrm{h}^{-1}\right)$.

The diesel oil density was corrected through the temperatures obtained by a type $\mathrm{K}$ thermocouple, previously registered at the fuel inlet and outlet on the flow meter, according to [eq. (6)].

$$
\mathrm{D}=844.14-(0.53 \times \mathrm{T})
$$

Where:

$\mathrm{D}$ is the diesel oil density $\left(\mathrm{g} \mathrm{L}^{-1}\right)$;

$\mathrm{T}$ is the diesel oil temperature $\left({ }^{\circ} \mathrm{C}\right)$, and

844.14 and 0.53 are parameters of the density regression.

Hourly consumption based on mass was determined as described by Lopes et al. (2003), according to [eq. (7)].

$$
\mathrm{HCM}=\left\{\frac{\mathrm{CFC} \times[844.14-(0.53 \times \mathrm{T})]}{1000}\right\}
$$

Where:

HCM is the hourly fuel consumption based on mass $\left(\mathrm{g} \mathrm{h}^{-1}\right)$;

HFC is the hourly fuel consumption based on volume $\left(\mathrm{L} \mathrm{h}^{-1}\right)$, and

1000 is the conversion factor.

The specific fuel consumption was determined considering the hourly fuel consumption based on mass due to the power available on the bar, according to [eq. (8)].

$$
\mathrm{SFC}=\left(\frac{\mathrm{CHM}}{\mathrm{PDB}}\right)
$$

Where:

SFC is the specific fuel consumption $\left(\mathrm{g} \mathrm{kW} \mathrm{h}^{-1}\right)$, and

PDB is the power available on the drawbar $(\mathrm{kW})$.

The efficiency on the drawbar was calculated from the power on the drawbar and tractor engine, considering the extra power ${ }^{6}(275 \mathrm{~kW})$, according to [eq. (9)].

$$
\mathrm{EDB}=\left(\frac{\mathrm{PDB}}{\mathrm{EP}}\right) \times 100
$$

6 The electronic motor software instantly activates the extra power (EPM) Due to the 
Where:

EDB is the efficiency on the drawbar (\%);

PDB is the power on the drawbar $(\mathrm{kW})$, and

$\mathrm{EP}$ is the engine power $(\mathrm{kW})$.

The engine thermal efficiency was obtained through the specific consumption and lower fuel calorific power, using [eq. (10)], according to Farias et al. (2017b).

$$
\mathrm{ETE}=\left(\frac{3600}{\mathrm{SFC} \times \mathrm{LHP}}\right)
$$

Where:

ETE is the engine thermal efficiency (\%), and

LHP is the lower heat power $\left(42,295 \mathrm{MJ} \mathrm{kg}^{-1}\right)$.

The tractor used in the experiment had an intercooler and turbine with variable geometry (VG), with the turbocharger pressure determined using a Motorola MPX
5700DP piezoresistive pressure transducer, allowing capturing the pressure in the engine inlet manifold during the experiment.

The inlet air temperatures in the engine and exhaust gases were measured during the experiment using type $\mathrm{K}$ thermocouples installed at the air filter inlet and tractor exhaust, respectively.

The collected data were submitted to normality (Shapiro-Wilk) and homogeneity (Brown-Forsythe) tests. Subsequently, they were subjected to analysis of variance (ANOVA) and, when significant, to the Tukey test, using the software Sigmaplot 14.

\section{RESULTS AND DISCUSSION}

Tables 1 and 2 show the results of the analysis of variance and the test of means for the analyzed variables. The coefficient of variation for all parameters was categorized as stable, according to the classification of Ferreira (2018).

TABLE 1. Summary of analysis of variance and test of means.

\begin{tabular}{|c|c|c|c|c|c|c|c|}
\hline $\begin{array}{l}\text { Remote control } \\
\text { valve (RCV) }\end{array}$ & $\begin{array}{l}\text { SLP } \\
(\%)\end{array}$ & $\begin{array}{c}\text { ES } \\
(\text { RPM) }\end{array}$ & $\begin{array}{c}\text { HFC } \\
\left(L^{-1}\right)\end{array}$ & $\begin{array}{l}\text { FDB } \\
(k N)\end{array}$ & $\begin{array}{c}\mathrm{OS} \\
\left(\mathrm{m} \mathrm{s}^{-1}\right)\end{array}$ & $\begin{array}{l}\text { PDB } \\
(\mathrm{kW})\end{array}$ & $\begin{array}{l}\text { EDB } \\
(\%)\end{array}$ \\
\hline $1 \mathrm{RCV}$ & 3.24 & $1,910 \mathrm{~B}$ & 57.48 & $101.99 \mathrm{~A}$ & $1.97 \mathrm{~A}$ & $200.78 \mathrm{~A}$ & $73.04 \mathrm{~A}$ \\
\hline 2 RCVs & 3.35 & $1,977 \mathrm{~A}$ & 61.46 & $100.81 \mathrm{~A}$ & $1.75 \mathrm{~B}$ & 176.14 B & $64.07 \mathrm{~B}$ \\
\hline $3 \mathrm{RCVs}$ & 3.48 & $1,958 \mathrm{~A}$ & 60.46 & $98.57 \mathrm{~B}$ & $1.70 \mathrm{C}$ & $167.75 \mathrm{C}$ & $62.02 \mathrm{C}$ \\
\hline CV (\%) & 12.46 & 1.69 & 4.69 & 2.27 & 6.71 & 8.16 & 8.16 \\
\hline \multicolumn{8}{|l|}{ F-test } \\
\hline RCV & $0.40 \mathrm{NS}$ & $23.83^{* *}$ & $2.36 \mathrm{NS}$ & $11.75^{* *}$ & $496.00 * *$ & $503.35^{* *}$ & $500.44 * *$ \\
\hline \multicolumn{8}{|l|}{ Normality } \\
\hline SW & 0.81 & 0.93 & 0.80 & 0.81 & 0.21 & 0.19 & 0.19 \\
\hline \multicolumn{8}{|l|}{ Homogeneity } \\
\hline BF & 0.73 & 0.26 & 0.77 & 0.44 & 0.35 & 0.51 & 0.52 \\
\hline
\end{tabular}

Parameters: wheel slip (SLP), engine speed (ES), hourly fuel consumption (HFC), force on the drawbar (FDB), operational speed (OS), power on the drawbar (PDB), and efficiency on the drawbar (EDB). Means followed by the same uppercase letter in each column within each factor do not differ from each other by the Tukey test $(\mathrm{P}<0.05)$. F-test of analysis of variance (ANOVA): NS - not significant; * $(\mathrm{P}<0.05)$ and $* *$ $(\mathrm{P}<0.01)$. CV: coefficient of variation. Shapiro-Wilk normality test: $\mathrm{SW} \leq 0.05$ - data abnormality; SW $>0.05-$ data normality. BrownForsythe variance homogeneity test: $\mathrm{BF} \leq 0.05$ - heterogeneous variances; $\mathrm{BF}>0.05$ - homogeneous variances.

The results obtained in the experiment described in Table 1 showed a significant difference for the parameters ES, FDB, OS, PDB, and EDB. The lowest number of activated remote control valves (1 RCV) provided high FDB, OS, and PDB, which directly interfere with the energy and operational performance of the agricultural tractor (Gabriel Filho et al., 2010; Farias et al., 2017a; Schlosser et al., 2017; Martins et al., 2018; Lopes et al., 2019), with no statistical difference in SLP and HFC.

Slippage showed no significant difference, with all results being below the range recommended by ASABE D496.3 (2011), which recommends 4 to $8 \%$ on concrete surfaces. These results were influenced by the ballast (tires) or selected speeds, as explained by Monteiro et al. (2011), with no interference regarding the number of RCVs in use.

The engine working speed was not fixed, and APM managed the gear number 8 for $1 \mathrm{RCV}$ and 7 for 2 and 3 RCVs to move at the target theoretical speed $\left(2.07 \mathrm{~m} \mathrm{~s}^{-1}\right)$. It provided an increase in ES of $3.51 \%$ for $2 \mathrm{RCVs}$ and $2.51 \%$ for $3 \mathrm{RCVs}$, which showed no difference from each other relative to $\mathrm{ES}$ for $1 \mathrm{RCV}$. The increased demand for hydraulic power provided by the increased RCVs in use forced APM to reduce the gear to 2 and $3 \mathrm{RCVs}$, explaining the significant decrease in OS compared to $1 \mathrm{RCV}$, thus interfering with $\mathrm{PDB}$ and EDB.

The variable HFC showed no difference regarding the number of RCVs in use, which occurred because SLP had no statistical difference and the efficiency of the APM resource maintained HFC constant, even varying gears (7 for $1 \mathrm{RCV}$ and 8 for 2 and $3 \mathrm{RCVs}$ ) and $\mathrm{ES}$, among the analyzed factors.

No significant difference was observed in FDB for 1 and 2 RCVs, with a statistical reduction in FDB when 3 RCVs were used. In the first case, the demand for hydraulic power from 1 to 2 RCVs was offset by gear reduction and increase in ES, both managed by APM, maintaining the same tractive force on the bar. However, in the second case ( 1 and 2 RCVs versus $3 \mathrm{RCVs}$ ), the management action was not sufficient to maintain the tractor effort, with a reduction in FDB for 3 RCVs because the priority for the APM 
resource was to maintain the supply of hydraulic flow at the required pressure, reducing the mechanical power available on wheels.

The use of 3 RCVs showed a significant decrease in the tractor pull capacity, leading to lower FDB and OS. Therefore, the tractor was not able to pull the required FDB and maintain the operational speed close to that of the theoretical target. The torque produced in the engine was the same because ES between 2 and 3 RCVs and HFC showed no statistical difference. However, the torque that would be available for the axle traction after transmission decreased due to an increase in demand for hydraulic power required in 3 RCVs, reflecting a lower FDB for 3 RCVs in use. These results converge to those found by Furlani et al. (2008) and diverge from those found by Silveira et al. (2013), who analyzed the energy demand of a seed-cum-fertilizer drill at different displacement speeds and engine speeds and obtained higher OS lower FDB.

The variable OS for $1 \mathrm{RCV}$ in use was 11.17 and $13.71 \%$ higher than 2 and $3 \mathrm{RCVs}$, respectively, proving the interference of the higher demand for hydraulic flow, requiring a high power from the engine that would be used to maintain OS. A reduction in OS directly implies a lower operational (Lopes et al., 2019) and energy performance (Macedo et al., 2016) of the mechanized set.

The power on the drawbar, which is the product between FDB and OS, was high according to the low number of RCVs in use, reflecting the behavior of its parameters. Jasper et al. (2016) found similar results when analyzing the performance of agricultural tractors under different gear management conditions.

The parameter EDB showed how much of the energy produced by the engine is available on the drawbar (Monteiro et al., 2013), which was reduced by the increased number of RCVs in use. The highest amount of energy produced in the engine to perform traction in the agricultural operation was obtained when only $1 \mathrm{RCV}$ was used. On the other hand, an increase in the number of remote control valves in use led to the need for a high oil flow, which is provided by a high engine power consumption available on the drawbar, reducing the tractor tractive capacity.

TABLE 2. Summary of analysis of variance and test of means.

\begin{tabular}{|c|c|c|c|c|c|c|c|}
\hline $\begin{array}{l}\text { Remote control } \\
\text { valve (RCV) }\end{array}$ & $\begin{array}{l}\text { FIT } \\
\left({ }^{\circ} \mathrm{C}\right)\end{array}$ & $\begin{array}{l}\text { FOT } \\
\left({ }^{\circ} \mathrm{C}\right)\end{array}$ & $\begin{array}{c}\mathrm{SFC} \\
\left(\mathrm{g} \mathrm{kW} \mathrm{h}^{-1}\right)\end{array}$ & $\begin{array}{l}\text { IT } \\
\left({ }^{\circ} \mathrm{C}\right)\end{array}$ & $\begin{array}{c}\mathrm{TP} \\
(\mathbf{k P a})\end{array}$ & $\begin{array}{l}\text { EGT } \\
\left({ }^{\circ} \mathrm{C}\right)\end{array}$ & $\begin{array}{l}\text { ETE } \\
(\%)\end{array}$ \\
\hline $1 \mathrm{RCV}$ & $33.52 \mathrm{~B}$ & $37.74 \mathrm{C}$ & $240 \mathrm{~B}$ & $25.62 \mathrm{C}$ & $213 \mathrm{~A}$ & $313.62 \mathrm{~B}$ & $35.54 \mathrm{~A}$ \\
\hline $2 \mathrm{RCVs}$ & $33.91 \mathrm{~B}$ & $40.88 \mathrm{~B}$ & $289 \mathrm{~A}$ & $26.77 \mathrm{~B}$ & $206 \mathrm{~B}$ & $343.56 \mathrm{~A}$ & $29.49 \mathrm{~B}$ \\
\hline 3 RCVs & $36.26 \mathrm{~A}$ & $46.53 \mathrm{~A}$ & $300 \mathrm{~A}$ & $28.07 \mathrm{~A}$ & $203 \mathrm{C}$ & $368.07 \mathrm{~A}$ & $28.47 \mathrm{~B}$ \\
\hline CV (\%) & 4.98 & 9.30 & 10.62 & 4.01 & 2.06 & 8.77 & 11.10 \\
\hline \multicolumn{8}{|l|}{ F-test } \\
\hline RCV & $7.41 *$ & $118.52 * *$ & $33.32 * *$ & $712.07 * *$ & $117.94 * *$ & $11.25 * *$ & $38.67 * *$ \\
\hline \multicolumn{8}{|l|}{ Normality } \\
\hline SW & 0.20 & 0.06 & 0.66 & 0.32 & 0.40 & 0.32 & 0.68 \\
\hline \multicolumn{8}{|l|}{ Homogeneity } \\
\hline$\overline{\text { BF }}$ & 0.84 & 0.80 & 0.99 & 0.70 & 0.96 & 0.56 & 0.80 \\
\hline
\end{tabular}

Parameters: engine fuel inlet temperature (FIT), engine fuel outlet temperature (FOT), specific fuel consumption (SFC), engine air intake temperature (IT), turbo pressure (TP), exhaust gas outlet temperature (EGT), and engine thermal efficiency (ETE). Means followed by the same uppercase letter in each column within each factor do not differ from each other by the Tukey test $(\mathrm{P}<0.05)$. F-test of analysis of variance (ANOVA): NS - not significant; * $(\mathrm{P}<0.05)$ and $* *(\mathrm{P}<0.01)$. CV: coefficient of variation. Shapiro-Wilk normality test: SW $\leq 0.05-$ data abnormality; SW $>0.05$ - data normality. Brown-Forsythe variance homogeneity test: $\mathrm{BF} \leq 0.05-$ heterogeneous variances; $\mathrm{BF}>0.05-$ homogeneous variances.

The increase in the number of RCVs in use led to a significant reduction in OS, mainly due to the higher energy demand with a higher number of operated valves. Thus, SFC (Table 2) with $1 \mathrm{RCV}$ in use presented the lowest value, mainly due to the higher OS and higher PDB value, corroborating the results obtained by Farias et al. (2017a).

The variable FIT was lower with 1 and 2 RCVs and higher for $3 \mathrm{RCVs}$, while FOT was higher as the number of RCVs $(1,2$, and 3 RCVs) in use increased. In this case, fuel was circulating inside of the system, which was undergoing heating during the process. Variation in fuel temperature can provide oscillation in density and, therefore, in SFC. A higher fuel temperature provides a reduction in density and, therefore, a high fuel volume is injected into the engine (Uzun, 2012), increasing SFC.

The engine air intake temperature (IT) varied in all treatments. This divergence is directly related to the time of the experiment, due to the change in the atmospheric air temperature during the day.
When the engine runs at a lower ES (1 RCV), both the compressor pressure and the air supply to the engine cylinders assumed lower values due to the low potential enthalpy of the exhaust gases leaving the cylinders, which are being transformed into work produced by the turbine, as explained by Giakoumis \& Tziolas (2018). However, the control system of the VG turbocharger is activated at this stage, reducing the turbine area by closing the vanes, resulting in the highest working pressure of the turbine for $1 \mathrm{RCV}$ and low for 2 and 3 RCVs.

Therefore, the highest TP for $1 \mathrm{RCV}$ promoted better energy efficiencies, thus providing a decrease in SFC, as observed by Farias et al. (2017b) when analyzing the air and fuel overfeed on the performance of the Diesel cycle engine.

A higher TP was observed for $1 \mathrm{RCV}$. Therefore, the mixture between fuel and oxidizer became poorer (higher air mass) in this treatment, as the tractor with an intercooler has a higher air mass admitted in the engine and hence more oxygen, resulting in the cooling of the mobile components 
and combustion chamber, besides providing a high air density within it, resulting in lower EGT for $1 \mathrm{RCV}$ and higher EGT for 2 and $3 \mathrm{RCVs}$, as the latter (2 and $3 \mathrm{RCVs}$ ) had higher ES and engine temperature, leading to a higher EGT. Uzun (2012) described similar results when performing a parametric study for the specific fuel consumption of a diesel engine with an intercooler using a neural network.

The engine thermal efficiency (ETE) is given as a function of the specific fuel consumption (SFC), as observed by Peça et al. (2010). Therefore, ETE was higher because SFC was lower for $1 \mathrm{RCV}$ in use, being $17.83 \%$ higher for $2 \mathrm{RCVs}$ and $19.05 \%$ higher for $3 \mathrm{RCVs}$. It corroborates with Farias et al. (2017b), who verified that a low SFC provides high ETE, thus evidencing the effectiveness of using implements that demand a low number of RCVs and providing a low SFC and high energy performance of the machinery.

\section{CONCLUSIONS}

The variation in the number of remote control valves in use showed no effect on the slippage, engine speed, and hourly fuel consumption of the agricultural tractor, but it interfered with the operational speed, power and efficiency on the drawbar, specific fuel consumption, turbo pressure, and engine thermal efficiency. In addition, these parameters were superior when a low number of remote control valves was used, thus interfering with the operational and energy performance of the agricultural tractor.

\section{REFERENCES}

Ajdadi FR, Gilandeh YA (2011) Artificial Neural Network and stepwise multiple range regression methods for prediction of tractor fuel consumption. Measurement 44(10):2104-2111. DOI:

https://doi.org/10.1016/j.measurement.2011.08.006

ASABE - American Society of Agricultural Biological Engineers (2011) ASABE EP 496.3 JUN11: Agricultural machinery management data. ASAE StandardS: standards engineering practices, 366-372p.

ASABE - American Society Of Agricultural Engineers (2011) ASABE EP 497.7 MAR11 Agricultural machinery management data. ASAE Standards: standards engineering practices, 373-380p.

Borghia M, Zardin B, Pintore F, Belluzzi F (2014) Energy savings in the hydraulic circuit of agricultural tractors. Energy Procedia 45(2014):352-361. DOI: https://doi.org/10.1016/j.egypro.2014.01.038

Boyer CN, Roberts RK, McClure AT, Tyler DD, Smith AS (2015) Effects of recent corn and energy prices on irrigation investment in the humid climate of Tennessee. Journal of Agricultural and Applied Economics 47(1):105122. DOI: https://doi.org/10.1017/aae.2014.4

Cutini M, Bisaglia C (2016) Development of a dynamometric vehicle to assess the drawbar performance of high-powered agricultural tractors. Journal of Terramechanics 65:73-84. DOI: https://doi.org/10.1016/j.jterra.2016.03.005
Farias MS, Schlosser JF, Linares P, Bertollo GM, Martini AT (2019) Reduction of fuel consumption using driving strategy in agricultural tractor. Revista Brasileira de Engenharia Agrícola e Ambiental 23(2):144-149

Farias MS, Schlosser JF, Linares P, Barbieri JP, Negri GM, Oliveira LFV, Rüdell IIP (2017a) Fuel consumption efficiency of an agricultural tractor equipped with continuously variable transmission. Revista ciência Rural 47(6). DOI: http://dx.doi.org/10.1590/0103$8478 \mathrm{cr} 20160814$

Farias MS, Schlosser JF, Martini AT, Santos GO, Estrada JS (2017b) Air and fuel supercharge in the performance of a diesel cycle engine. Revista Ciência Rural 47(6):e20161117 DOI: http://dx.doi.org/10.1590/0103$8478 \mathrm{cr} 20161117$

Ferreira PV (2018) Estatística experimental aplicada as ciências agrarias. Viçosa, MG, UFV, 126p.

Furlani CEA, Silva RP, Filho AC, Cortez JW, Grotta DCC (2008) Semeadora-adubadora: exigências em função do preparo do solo, da pressão de inflação do pneu e da velocidade. Revista Brasileira de Ciência do Solo 32(1):345-352. DOI: http://dx.doi.org/10.1590/S010006832008000100032

Giakoumis EG, Tziolas V (2018) Modeling a variablegeometry turbocharged diesel engine under steady-state and transient conditions. Journal of Energy Engineering 144(3):04018017 DOI:

https://doi.org/10.1061/(ASCE)EY.1943-7897.0000537

Gabriel Filho FA, Lanças KP, Leite F, Acosta JJ, Jesuino PR (2010) Desempenho de trator agrícola em três superfícies de solo e quatro velocidades de deslocamento. Revista Brasileira de Engenharia Agrícola e Ambiental 14(3):333-339. DOI: http://dx.doi.org/10.1590/S141543662010000300015

Jasper SP, Bueno LSR, Laskoski M, Langhinotti CW, Parize GL (2016) Desempenho do trator de 157KW na condição manual e automático de gerenciamento de marchas. Revista Scientia Agraria 17(3):55. DOI: http://dx.doi.org/10.5380/rsa.v17i3.50998

Lankenau GF, Diaz AG, Winter V (2019) An engineering review of the farm tractor's evolution to a dominant design. Journal of Mechanical Design 141(3):1-12. DOI: https://doi.org/10.1115/1.4042338

Lopes A, Lanças KP, Furlani CEA, Nagaoka AK, Neto PC, Grotta DCC (2003) Fuel consumption of a tractor as a function of the tyre type, ballasting and forward speed. Revista Brasileira de Engenharia Agrícola e Ambiental 7(2):382-386. DOI: http://dx.doi.org/10.1590/S141543662003000200033

Lopes JEL, Chioderoli CA, Monteiro LA, Santos MAM, Cleef EHCB, Nascimento SEM (2019) Operational and energy performance of the tractor-scarifier assembly: Tires, ballasting and soil cover. Revista Brasileira de Engenharia Agrícola e Ambiental 23:800-804. DOI: https://dx.doi.org/10.1590/18071929/agriambi.v23n10p800-804 
Macedo DXS, Nicolau FEA, Nascimento HCF, Costa E, Chioderoli CA, Loureiro DR (2016) Operational performance of a tractor-seeder according to the velocity and working depth. Revista Brasileira de Engenharia Agrícola e Ambiental 20(3):280-285. DOI:

http://dx.doi.org/10.1590/1807-1929/agriambi.v20n3p280-285

Mantovani EC, Oliveira PEB, Queiroz DM, Fernandes ALT, Cruvinel PE (2019) Current status and future prospect of the Agricultural Mechanization Situation in Brazil. AMA-Agricultural Mechanization in Asia Africa and Latin America 50(2):20-28.

Martins MB, Sandi J, Souza FL, Santos RS, Lanças KP (2018) Otimização energética de um trator agrícola utilizando normas técnicas em operações de gradagem. Engenharia na Agricultura 26:52-57. DOI: https://doi.org/10.13083/reveng.v26i1.852

Masiero FC, Lanças KP, Monteiro LA (2011)

Determinação do rendimento na barra de tração de tratores agrícolas com tração dianteira auxiliar (4X2 TDA). Revista Energia na Agricultura 26(4):55-73. DOI: https://doi.org/10.17224/EnergAgric.2011v26n4p55-73

Mialhe LG (1980) Máquinas motoras na agricultura. São Paulo, USP, 139p.

Molari G, Sedoni E (2008) Experimental evaluation of power losses in a power-shift agricultural tractor transmission. Biosystems Engineering 100(2):177-183. DOI: https://doi.org/10.1016/j.biosystemseng.2008.03.002

Monteiro LA, Lanças KP, Guerra SPS (2011) Desempenho de um trator agrícola equipado com pneus radiais e diagonais com três níveis de lastros líquidos. Engenharia Agrícola 31(3):551-560. DOI: http://dx.doi.org/10.1590/S0100-69162011000300015

Monteiro LA, Albiero D, Souza FH, Melo RP, Cordeiro IM (2013) Rendimento na barra de tração de um trator agrícola com diferentes relações de peso e potência. Revista Ciência Agronômica 44(1):70-75. DOI: http://dx.doi.org/10.1590/S1806-66902013000100009

Peça JO, Serrano JM, Pinheiro A, Carvalho M, Nunes M, Ribeiro L, Santos F (2010) Speed advice for power efficient drawbar work. Journal of Terramechanics 47(1):55-61. DOI: https://doi.org/10.1016/j.jterra.2009.07.003
Rinaldi PCN, Fernandes HC, Teixeira MM, Cecon PR, Alvarenga CB (2016) Diagnóstico da potência e torque dos tratores agrícolas fabricados e comercializados no Brasil. Revista Engenharia na Agricultura 23:246-256. DOI: http://dx.doi.org/10.13083/1414-3984/reveng.v24n3p246-256

Roeber JBW, Pitla SK, Kocher MF, Luck JD, Hoy RM (2016) Tractor hydraulic power data acquisition system. Computers and Electronics in Agriculture 127:1-14. DOI: https://doi.org/10.1016/j.compag.2016.05.012

Schlosser JF, Farias MS, Estrada JS, Santos GO, Gil E (2017) Performance and emission of pollutants of an agricultural engine with two power take-off settings. Engenharia Agrícola 37:277-285. DOI: https://dx.doi.org/10.1590/1809-4430eng.agric.v37n2p277-285/2017

Silveira JCM, Fernandes HC, Modolo AJ, Silva SL, Togrello E (2013) Demanda energética de uma semeadoraadubadora em diferentes velocidades de deslocamento e rotações do motor. Revista Ciência Agronômica 33(1):4452. DOI: http://dx.doi.org/10.1590/S180666902013000100006

Simikić M, Dedovic' N, Savin L, Tomic' M, Ponjican O (2014) Power delivery efficiency of a wheeled tractor at oblique drawbar force. Soil \& Tillage Research 141:32-43. DOI: http://dx.doi.org/10.1016/j.still.2014.03.010

Simikić M, Dedovic' N, Savin L, Tomic' M, Stllelı HH, Ponjican O (2012) Influence of eccentric drawbar force on power delivery efficiency of a wheeled tractor. Turkish Journal of Agriculture \& Forestry 36(4):486-500. DOI: https://doi.org/10.3906/tar-1012-1616

Uzun A (2012) A parametric study for specific fuel consumption of an intercooled diesel engine using a neural network. Fuel 93:189-199. DOI: https://doi.org/10.1016/j.fuel.2011.11.004

Wienecke D, Bartz W (1999) Influence of Base Oil and Formulation of Gear Oils on Friction Power Losses of Gears. SAE Technical Paper 1999-01-3465p. DOI: https://doi.org/10.4271/1999-01-3465 